JIPSINDO No. 1, Volume 2, Maret 2015

\title{
MUATAN NILAI-NILAI KARAKTER MELALUI PERMAINAN TRADISIONAL DI PAUD AMONG SIWI, PANGGUNGHARJO, SEWON, BANTUL
}

\author{
Sudrajat, Taat Wulandari, Agustina Tri Wijayanti \\ Pendidikan IPS Fakultas Ilmu Sosial UNY \\ Email: sudrajat73@gmail.com. Hp.085743430029
}

\begin{abstract}
Abstrak
Penelitian ini bertujuan untuk mengetahui muatan nilai-nilai karakter melalui permainan tradisional di PAUD Among Siwi, Panggungharjo, Sewon, Bantul. Subjek penelitian ini adalah seluruh siswa PAUD Among Siwi dan pendidik. Teknik pengumpulan data menggunakan observasi dan wawancara. Desain penelitian yang digunakan dalam penelitian ini berbentuk kualitatif. Teknik analisis data digunakan analisis model interaktif. Hasil penelitian menyimpulkan bahwa proses pembelajaran di Among Siwi ditekankan pada pengembangan karakter dan budaya. Penanaman karakter melalui permainan tradisional dapat dilihat melalui permainan seperti sluku-sluku bathok, ancak-ancak alis, dempo ewaewo, baris rampak, dsb. Dalam permainan, tarian dan nyanyian aspek yang terkandung seperti Wiroso (perasaan), Wiromo (irama), Wirogo (psikomotorik/ketrampilan), sehingga nilai-nilai karakter yang tertanam dalam diri anak seperti kerjasama, kebersamaan, kreatifitas, tanggung jawab, demokrasi, percaya diri, komitmen, dapat berkembang dengan baik sejak usia dini.
\end{abstract}

Kata kunci : nilai-nilai karakter, permainan tradisional 


\begin{abstract}
This study aims to determine the charge character values through traditional games in early childhood Among Siwi, Panggungharjo, Sewon, Bantul. The subjects were all students of early childhood educators Among Siwi. Data collection technique used observation and research interview. Desain used in this study is qualitative. Data analysis techniques used interactive model analysis. The research concludes that the learning process in Siwi Among emphasis on character development and culture. Planting character through traditional games can be seen through the game as sluku-sluku bathok, nonchalant eyebrow, Dempo ewa-Ewo, etc, baris rampak. In games, dances and songs contained aspects such as Wiroso (feeling), wiromo (rhythm), Wirogo (psychomotor/skills), so that the character values that are embedded in the child such as cooperation, solidarity, creativity, responsibility, democracy, trust self, commitment, can develop well from an early age.
\end{abstract}

Keywords: the values of character, traditional games

\title{
Pendahuluan
}

Permasalahan yang dihadapi bangsa Indonesia sangat kompleks, hal ini dibuktikan dengan berbagai permasalahan sosial yang melanda masyarakat kita, masalah harta, kedudukan, pangkat dan kekuasaan selalu didewakan dan dipentingkan sehingga banyak terjadi pergeseran nilai yang tumbuh di masyarakat.Pergeseran nilainilai dibuktikan dengan perubahan nilai-nilai sosial, ekonomi dan kultural. Masalah kriminalitas semakin tinggi, kasus pembunuhan semakin sulit dihindari, kenakalan remaja seperti narkoba, seks bebas, tawuran, fenomena geng motor semakin bertambah, dan sampai masalah harga diri bangsa juga semakin dipertaruhkan. Selain itu, perilaku remaja sekarang cenderung cuek, tidak ada rasa peduli, dan kurang sopan santun dan masih banyak permasalahan moral dan karakter yang melanda masyarakat kita. 
Karakter bangsa merupakan aspek penting dari pembentukan kualitas sumber daya manusia karena kualitas karakter bangsa menentukan kemajuan suatu bangsa dan negara. Peningkatan kualitas sumber daya manusia dapat ditempuh melalui perbaikan sistem pendidikan yang mengarah pada pembentukan karakter siswa sejak tingkat pra sekolah sampai perguruan tinggi. Pembentukan karakter sebagai upaya meningkatkan perilaku individu dilaksanakan secara berkesinambungan yang melibatkan aspek knowledge, feeling, dan acting (Tadkiroatun Musfiroh, 2008: 31).

Nilai-nilai karakter dapat diinternalisasikan melalui lingkungan keluarga, sekolah maupun masyarakat. Karena proses penanaman karakter merupakan proses untuk membentuk, menumbuhkan, mengembangkan dan mendewasakan kepribadian anak menjadi pribadi yang bijaksana dan bertanggung jawab melalui pembiasaanpembiasaan pikiran, hati dan tindakan secara berkesinambungan yang hasilnya dapat terlihat dalam tindakan nyata sehari-hari baik di keluarga, sekolah maupun di masyarakat. Nilai-nilai karakter yang terintegrasi meliputi dimensi penting yang dapat digambarkan dalam beberapa tindakan, maksudnya pendekatan pendidikan karakter dalam keluarga dapat terintegrasi melalui proses interaksi dalam masyarakat, antara orang tua dan anak dapat bekerja sama dalam proses sosialisasi yang berorintasi pada tindakan yang lebih bermakna, sehingga proses internalisasi dan sosialisasi dapat membantu dalam pembentukan pribadi anak yang berkarakter baik dan berakhlak mulia.

Wilayah Pandes Kabupaten Bantul termasuk wilayah yang konsisten mengembangkan tradisi lokal dan nilai-nilai budaya Jawa. Berawal dari keprihatinan warga terhadap perkembangan anak-anak 
sekarang yang cenderung meniru budaya-budaya barat mulai dari pola perilaku, kebiasaan dan pola pikir yang sudah jauh dari tata norma dan aturan yang ada. Termasuk jenis permainan atau doalanan anak yang sekarang beralih pada permainan modern (play stations, game internet, dll). Warga Pandes, Bantul kemudian menawarkan solusi alternative dengan membentuk Kampung Dolanan. Sesuai dengan namanya, warga Pandes berkomitmen akan mengedepankan nilai-nilai budaya sebagai solusi dalam mengatasi berbagai permasalahan moral, sosial dan kultural masyarakat. Kampung Dolanan mengenalkan kembali permainan-permainan tradisional (dolanan anak) kepada anak-anak, contohnya seperti sluku-sluku bathok, ancak-ancak alis, egrang, congklak/dakon, benthik, cublak-cublak suweng, bandulan, gobak sodor, engklek, dll, diharapkan melalui permainan tradisional tersebut generasi muda termasuk anak-anak lebih memahami dan memaknai bahwa melalui permainan tradisional diajarkan untuk saling toleransi, menghormati, kebersamaan, kejujuran, sportif, keberanian, konsisten, mandiri, serta tanggung jawab. Maka dari itu, penelitian ini akan melihat bagaimana nilai-nilai karakter yang dikembangkan melalui permainan tradisional di Among Siwi, Kampung Dolanan, Desa Pandes, Panggungharjo, Sewon, Bantul.

\section{Hakekat Karakter}

Lickona (1992: 51) menjalaskan tentang pengertian karakter sebagai berikut:

Character consist of operative values, values in action. Character conceived has three interrelated parts: moral knowing, moral feeling and moral behavior. Good character consists of knowing the good, desiring the good and doing the good-habits of the mind, habits of the heart and habits of action. 
JIPSINDO No. 1, Volume 2, Maret 2015

Pernyataan di atas dapat dijelaskan bahwa karakter terdiri dari nilai-nilai tindakan. Karakter yang dipahami mempunyai tiga komponen saling berhubungan yaitu pengetahuan moral, perasaan moral dan perilaku moral. Karakter yang baik terdiri dari pengetahuan yang baik, menginginkan yang baik dan melakukan kebiasaan yang baik pula dari pikiran, kebiasaan dan tindakan.

Tadkiratun Musfiroh (2008: 27) menjelaskan bahwa karakter mengacu pada serangkaian sikap perilaku (behavior), motivasi (motivations), dan keterampilan (skills), meliputi keinginan untuk melakukan hal yang terbaik.Maksudnya bahwa pendidikan karakter adalah usaha yang sengaja dilakukan untuk membantu masyarakat, memahami perilaku orang lain, peduli dan bertindak serta memiliki ketrampilan atas nilai-nilai etika.

Tujuan pendidikan watak atau karakter menurut Darmiyati Zuchdi (2008: 39) untuk mengajarkan nilai-nilai tradisional tertentu, nilai-nilai yang diterima secara luas sebagai landasan perilaku yang baik dan bertanggung jawab.Nilai-nilai ini digambarkan sebagai perilaku moral. Proses pembelajaran karakter lebih diarahkan pada aspek pengetahuan, ketrampilan dan perilaku, seperti yang diungkapkan Barth (1990: 254) terdapat tiga aspek dalam pembelajaran yang harus dicapai yaitu; "a) knowledge, which is a body of fact and principles; b) skill, which is acquiring an ability through experience or training; c) attitude, which is one's opinion, feeling or mental set as demonstrated by one's action".

Pernyataan di atas dapat dijelaskan bahwa tiga aspek dalam pembelajaran meliputi a) pengetahuan, adalah bentuk dari prinsip dan fakta; b) ketrampilan, adalah pemerolehan kemampuan melalui pelatihan atau pengalaman; c) sikap, adalah suatu pendapat, 
perasaan atau mental seseorang yang ditunjukkan oleh tindakan. Lickona (1992: 53) mendefinisikan tiga komponen dalam membentuk karakter yang baik, yaitu:

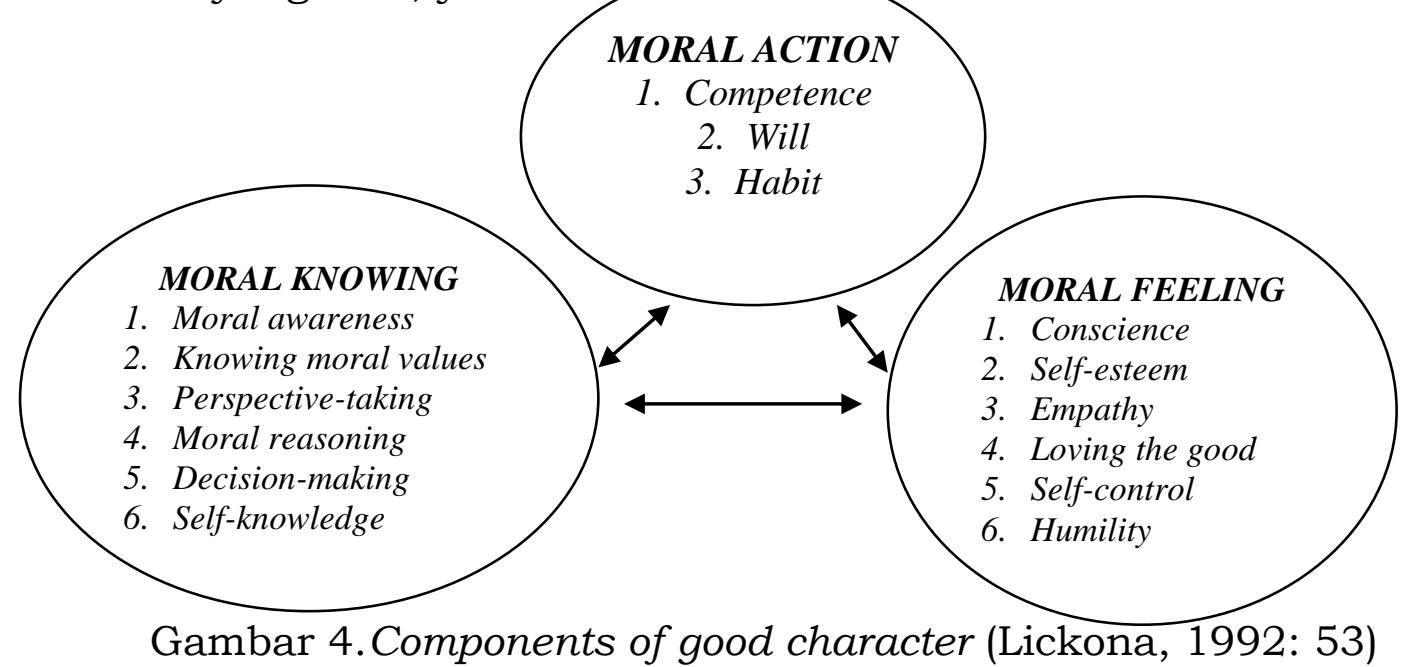

Gambar 4 dapat dijelaskan bahwa masing-masing komponen mempunyai aspek yang saling berhubungan satu sama lain. Aspek dari tiga komponen karakter adalah: Moral knowing yaitu 1) kesadaran moral (moral awarenees), 2) mengetahui nilai moral (knowing moral values), 3) perspective taking, 4) penalaran moral (moral reasoning) 5) membuat keputusan (decision making) 6) pengetahuan diri (self knowledge). Unsur moral knowing mengisi ranah kognitif siswa. Sedangkan moral feeling, enam hal yang merupakan aspek dari emosi yang harus mampu dirasakan oleh seseorang untuk menjadi manusia berkarakter yaitu: 1) nurani (conscience), 2) penghargaan diri (self esteem), 3) empati (empathy), 4) cinta kebaikan, kasih sayang (loving the good), 5) kontrol diri (self control) dan 6) kerendahan hati (humility). Moral actions merupakan perbuatan atau tindakan moral dari dua komponen karakter lainnya. Untuk memahami apa yang mendorong seseorang untuk berbuat (act 
JIPSINDO No. 1, Volume 2, Maret 2015

morally) maka harus dilihat tiga aspek lain dari karakter yaitu kompetensi (competence), keinginan (will), dan kebiasaan (habit).

Dapat disimpulkan bahwa untuk mengembangkan karakter melalui tahap pengetahuan (knowing), kemudian berbuat (acting), menuju kebiasaan (habit) dimaksudkan bahwa karakter tidak sebatas pada pengetahuan saja, akan tetapi perlu ada perlakuan dan kebiasaan untuk berbuat sehingga membentuk karakter yang baik. Karena pendidikan karakter merupakan proses untuk membentuk, menumbuhkan, mengembangkan dan mendewasakan kepribadian anak menjadi pribadi yang bijaksana dan bertanggung jawab melalui pembiasaan-pembiasaan pikiran, hati dan tindakan secara berkesinambungan yang hasilnya dapat terlihat dalam tindakan nyata sehari-hari baik di sekolah maupun di masyarakat.

Sjarkawi (2006: 70) menjelaskan bahwa dalam dunia pendidikan, nilai merupakan salah satu bagian dari pendidikan afektif. Tujuan dari pendidikan afektif adalah membantu siswa agar meningkat dalam aspek afektif, dari tingkat paling bawah (menerima pernyataan tentang nilai-nilai) kemudian menghargainya, merasa komitmen terhadap nilai-nilai itu dan akhirnya menginternalisasikan sistem nilai sebagai tingkat tertinggi dalam perkembangan afektif atau sikap. Kirschenbaum (1995: 31) menjelaskan bahwa:

A comprehensive values education utilized many of the methods and activities from the values realization, character education, citizenship education and moral education. The first four categories illustrate one important aspect of comprehensive values education. The categories of inculcating, modeling, facilitating, and skill-building all emphasize the comprehensive nature of the task. 
Pernyataan di atas mempunyai pengertian bahwa pendidikan nilai yang komprehensif yang meliputi inculcation (inkulkasi), fasilitation (fasilitasi), dan pembinaan ketrampilan (skill building). Pendekatan penanaman nilai (inkulkasi) mengusahakan agar siswa mengenal dan menerima nilai sebagai milik mereka dan bertanggung jawab atas keputusan yang diambilnya melalui tahap mengenal pilihan, menilai pilihan, menentukan pilihan, menentukan pendirian, menerapkan nilai sesuai dengan keyakinan diri.

Muhammad Ali (2005: 144) menjelaskan bahwa nilai merupakan tatanan atau kriteria dalam diri individu yang dijadikan dasar untuk mengevaluasi suatu sistem. Pertimbangan nilai merupakan penilaian individu terhadap objek yang didasarkan pada nilai tertentu yang akan membentuk pada sebuah moral individu. Moral merupakan tatanan perilaku yang memuat nilai-nilai tertentu untuk dilakukan individu dalam hubungannya dengan individu lain di masyarakat. Dalam moralitas terkandung aspek-aspek kognitif, afektif dan perilaku. Dengan demikian dapat disimpulkan bahwa nilai merupakan dasar pertimbangan bagi individu untuk melakukan sesuatu. Moral merupakan perilaku yang seharusnya dilakukan atau tidak dilakukan sedangkan sikap merupakan kecenderungan individu untuk merespon terhadap sekumpulan objek sebagai perwujudan sistem nilai dan moral dalam dirinya.

Barth (1990: 370) menjelaskan bahwa nilai adalah "the results of judgments made by an individual or the society as a whole which determine the relative importance or worth of a thing, idea, practice or believe". Penjelasan di atas dapat disimpulkan bahwa nilai merupakan hasil pertimbangan yang dibuat oleh seseorang atau masyarakat secara kelompok untuk menentukan penting atau 
JIPSINDO No. 1, Volume 2, Maret 2015

berharganya suatu hal, gagasan, atau praktek. Pengertian sikap kaitannya dengan perilaku dijelaskan Rokeach (Bimo Walgito, 1991: 108) bahwa "an attitude is a relatively enduring organixation of beliefs around an object or situation predisposing one to respond in some preferential manner". Pernyataan di atas dijelaskan bahwa pengertian sikap termasuk komponen kognitif dan konatif yang merupakan predisposing atau kecenderungan untuk merespon dan berperilaku. Ini berarti bahwa sikap merupakan kecenderungan untuk berbuat atau berperilaku.

Yuon Ambroise (Kaswardi, 1993: 20) menjelaskan bahwa hubungan antara nilai, sikap dan perilaku serta kepribadian seseorang seperti yang tertera dalam gambar 2 berikut ini:

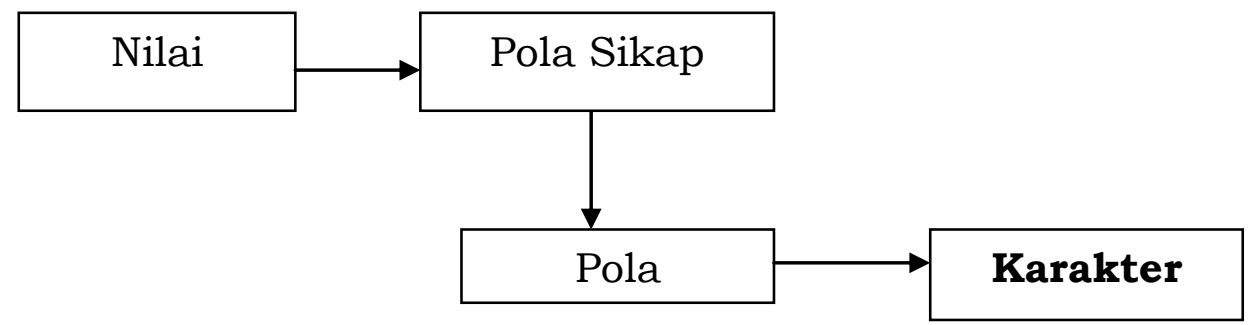

Gambar 2. Hubungan antara nilai, sikap, perilaku dan kepribadian.

Dari gambar 2, menunjukkan bahwa nilai hidup seseorang akan menjadi acuan dalam menentukan sikap dan menentukan seseorang dalam berperilaku. Jadi pengetahuan tentang nilai dapat membentuk sikap, perilaku yang mencerminkan kepribadian atau karakter seseorang. Hal senada diungkapkan Hart (1978: 5) terdapat hubungan antara nilai, sikap dan perilaku yaitu:

The relationship between values and behavior cannot clearly be understood without mentioning attitude. Whereas values refer to general modes of behavior or end-state of existence across situations, attitudes are tied to specific events, persons or objects. 
Pernyataan di atas maksudnya adalah hubungan antara perilaku dan nilai-nilai tidak dapat dijelaskan tanpa adanya suatu sikap. Sedangkan nilai-nilai mengacu pada perilaku yang umum dari keberadaan situasi tertentu, sikap seseorang atau objek tertentu. Pernyataan tersebut dapat dijelaskan melalui gambar seperti di bawah ini.

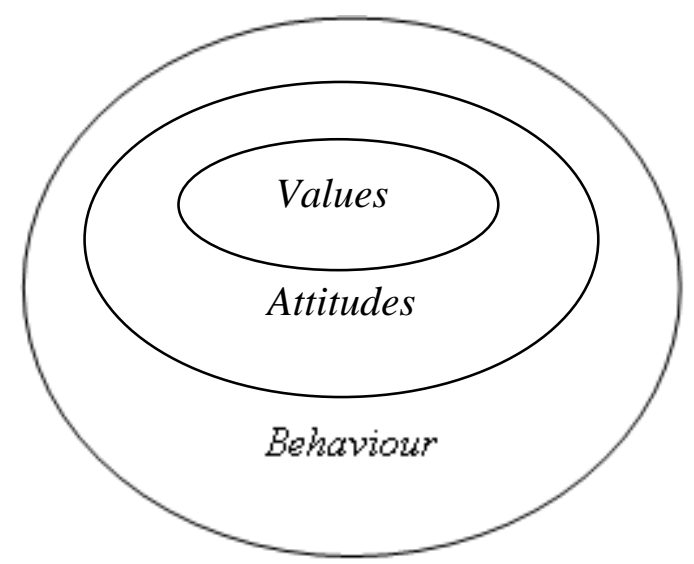

Gambar 3. The relationship between values, attitudes and behaviours. (Hart, 1978: 6)

Bimo Walgito (2002: 109) menjelaskan bahwa sikap merupakan organisasi pendapat, keyakinan seseorang mengenal objek atau situasi yang relative ajeg yang disertai adanya perasaan tertentu dan memberikan dasar kepada orang tersebut untuk membuat repon atau perilaku dalam cara-cara tertentu yang dipilihnya, jadi sikap dapat melahirkan pendapat, nilai dan perilaku.

Ramli Zakaria (2008: 2) menjelaskan terdapat hubungan antara sikap, perilaku dengan nilai, bahwa sikap dan nilai merupakan kostruk hipotetik dan menjadi dorongan bagi terwujudnya perilaku seseorang. Perbedaan antara nilai dan sikap adalah nilai lebih bersifat global dari sikap dan menjadi sasaran yang lebih abstrak 
JIPSINDO No. 1, Volume 2, Maret 2015

dalam membuat pertimbangan dan mengambil keputusan. Maka dari itu nilai dapat mempengaruhi pula perilaku atau perbuatan seseorang dengan mempengaruhi sikap dan penilaian terhadap perilaku tersebut. Jadi dapat disimpulkan bahwa nilai sebagai kunci bagi munculnya perilaku seseorang.

\section{Permainan Tradisional}

Pelestarian seni dan permainan tradisional sebagai salah satu bentuk kekayaan budaya nusantara memang harus bersikap adil, dalam arti dapat memberi perhatian sesuai dengan kebutuhan.Wujudu pelestarian seni dan permainan tradisional dapat dilakukan dalam bentuk kontrol (pengawasan) dan supporting dari masyarakat. Tanpa hal itu, pelestarian tidak dapat dilakukan secara maksimal. Apabila seni tradisional tersebut memiliki kendala dalam hal pengembangan dan pelestarian, baik tidak adanya wadah untuk berkesenian atau kepedulian generasi muda setempat yang rendah, maka perlu kerja ekstra dan perhatian serius terutama dari peran pemerintah untuk merevitalisasikan seni budaya tradisional agar dikenal dan dapat berkembang.

Langkah sederhana yang tak kalah pentingnya adalah memberi pengertian tentang seni tradisional itu sendiri, baik dalam hubungannya dengan sesama seni tradisional di dalam wadah budaya Indonesia, maupun seni tradisional dalam kaitannya dengan bagian dari seni global. Tanpa memberi pengertian yang jelas, dikhawatirkan akan muncul pemahaman yang keliru sehingga menganggap bahwa seni tradisional adalah sesuatu yang kuno, yang tidak bergengsi, norak, udik, sehingga tidak perlu dilestarikan. Pemahaman yang keliru juga bisa menyebabkan orang menjadi tidak peduli pada setiap seni tradisional terutama permainan tradisional 
yang sekarang sudah mulai ditinggalkan dengan permainan (gadget modern), yang secara tidak langsung akan mempengaruhi cara berpikir dan bersikap generasi mendatang menjadi generasi yang kurang memahami tata aturan dan norma di masyarakat.

Setiap permaian tradisional menampilkan sisi tersendiri untuk perkembangan kecerdasan anak baik kecerdasan intelektual, spiritual maupun emotional.Hal ini sangat berbeda sekali dengan permainan modern yang berkembang saat ini. Beberapa pesan moral yang dapat disampaikan oleh permainan tradisional :

a. Permainan tradisional mengajarkan untuk berbagi kepada sesama teman, karena permainan menuntut mereka untuk berinteraksi langsung dengan lawan main.

b. Masing-masing pemain harus dapat bersikap sportif pada setiap permaian yang dilakukan dan harus dapat menerima jika dia kalah.

c. Setiap pemain harus menyelesaikan setiap permainan dari awal sampai akhir permainan, tidak boleh berhenti di tengah permainan (tidak boleh putus asa).

d. Masing-masing pemain akan berpikir kreatif terhadap hal-hal yang ada disekelilingnya sehingga diharapkan kelak anak-anak tersebut menjadi manusia dewasa yang kreatif (dalam hal positif tentunya).

\section{Metode Penelitian}

Penelitian ini menggunakan metode kualitatif, metode ini menyajikan temuannya dalam bentuk deskripsi kalimat yang rinci, lengkap, dan mendalam mengenai proses mengapa dan bagaimana sesuatu terjadi. Teknik pengumpulan data menggunakan 1) teknik wawancara mendalam (in depth interviewing), dalam penelitian ini dilakukan dengan pertanyaan yang bersifat terbuka (open-ended) dan 
mengarah pada kedalaman informasi serta dilakukan tidak secara formal terstruktur guna menggali pandangan subjek yang diteliti tentang banyak hal yang sangat bermanfaat untuk menjadi dasar bagi penggalian informasi secara lebih jauh, lengkap, dan mendalam. 2) Observasi, dilakukan untuk melihat penanaman nilai-nilai karakter melalui permainan tradisional. 3) analisisdokumen, sebagai pelengkap dari data yang dikumpulkan melalui wawancara.

Teknik validitas data dalam penelitian ini menggunakan teknik trianggulasi. Penelitian ini menggunakan teknik trianggulasi data dan trianggulasi metode. Analisis data menggunakan teknik analisis model interaktif yang memiliki tiga langkah utama yaitu reduksi data, sajian data, dan penarikan simpulan.

\section{Hasil Penelitian}

Dalam pelestarian nilai-nilai tradisi tersebut metode atau cara yang dilakukan masyarakat Pandes, Bantul adalah dengan merevitalisasikan nilai tradisi tersebut. Landasan nilai yang dikembangkan di masyarakat Pandes sebagai desa budaya adalah :

1. Kesadaran akan ruh geografis

Pada zaman nenek moyang sudah dikembangkan di wariskan berbagai dolanan tradisional, masyarakat mengembangkan dolanan tersebut dengan memanfaatkan potensi lingkungan sekitar, misalnya seperti dolanan kitiran.Dimana dolanan kitiran sangat mengandalkan kekuatan angina untuk memutar baling-baling tersebut.Selain itu, masyarakat memanfaatkan potensi lingkungan sekitar untuk mengembangkan dolanan tradisional lebih luas lagi.

2. Kreativitas dan Kemandirian

Dari zaman dulu, masyarakat khususnya simbah-simbah di kampong Pandes sudah sangat kreatif, karena mampu membuat, 
menciptakan, dan mengembangkan sendiri bermacam-macam dolanan tradisional dengan berbagai bentuk dan warna.Misalnya menciptakan dolanan otok-otok dengan memanfaatkan bamboo yang dapat bersuara hanya dari selembar kecil cumpring. Selain itu, juga mampu membuat wayang dari kertas tanpa harus membuat bentuk pola terlebih dahulu, tidak hanya 1 karakter wayang saja tetapi sampai 90 karakter wayang juga dikembangkan dengan berbagai bentuk dan warna.

Dari kreatifitas tersebut dapat menciptakan kemandirian dan tidak tergantung orang lain untuk dapat bertahan hidup. Masyarakat optimis dengan bekal kreatifitas yang mereka punya, dapat membantu mencukupi kebutuhan sehari-hari, paling tidak mereka mendapatkan uang untuk bekal hidup melalui cara yang halal.

\section{Pendidikan Karakter}

Dari bermacam-macam dolanan yang diciptakan ternyata ada maksud yang hendak dicapai, seperti dengan adanya berbagai dolanan tradisional dapat merangsang kecerdasan majemuk secara optimal.Jauh sebelum Gardner menyimpulkan kecerdasan majemuk pada anak, masyarakat Pandes melalui hasil karya simbah-simbah tersebut sudah memahami lebih dulu tentang kecerdasan yang ada dalam diri anak-anak, berbeda dengan Gardner yang hanya menyimpulkan saja. Selain itu, mengembangkan kecerdasan anak tidak hanya melalui permaina tradisional saja tetapi juga melalui nyanyian yang di dalamnya terdapat beberapa hal seperti Wiroso (perasaan), Wiromo (irama), Wirogo (psikomotorik/ketrampilan), ketiga hal tersebut tidak dimiliki oleh permainan di era sekarang. 
Masyarakat menyadari bahwa penanaman nilai-nilai karakter terutama dalam diri anak-anak sangat diperlukan, sehingga sampai sekarang masyarakat masih mempertahankan dan mengembangkan dolanan tradisional, nyanyian dan tari tradisional.Atas dasar itulah, perlu dikembangkan dalam rangka mengembangkan karakter dalam diri anak melalui layanan pendidikan.Karena, pendidikan merupakan hal yang penting untuk mencapai kecerdasan baik pengetahuan, sikap maupun ketrampilan. Sehingga, dibentuklah layanan pendidikan melalui Pendidikan Anak Usia Dini "Among Siwi”.

Sekolah yang berbasis Budaya berdiri pada tahun 2006, yang dinamakan Sekolah Among Siwi sekarang menjadi Pendidikan Anak Usia Dini (PAUD) Among Siwi. Tempatnya dibagi menjadi dua tempat kerena terdapat dua kelas, yaitu A dan B. Bangunannya kecil, hanya terbuat dari bilik bambu sehingga membentuk sebuah pondok taman bermain untuk anak-anak di Desa Pandes. Keceriaan anak-anak, tergambar jelas, mereka bermain, berteriak, gulingguling di lantai, berlari kesana kemari di sekolah kecil itu. Pendidik di Among siwi menyambut hangat semangat anak-anak untuk belajar, sekalipun pendidik yang mengajar sering kewalahan, menghadapi anak-anak, bahkan tidak cukup satu orang guru, melainkan dua atau tiga guru sekaligus ikut membantu dalam mentertibkan murid di Among siwi. jam belajar di among siwi dimulai dari jam 7.30 wib sampai 10.00 wib, anak -anak pun diantar dan dijemput bersama orang tua masing-masing.

Terbentuknya PAUD Among Siwi didukung oleh masyarakat setempat dan pimpinan masyarakat sampai tingkat kabupaten. Visi dan Misi yang dibentuk: 
Visi : Mencipatakan tatanan masyarakat yang religious, demokratis, berdaya secara ekonomi serta berkesadaran ekologis untuk membangun sekolah masa depan yang mampu memberi makna lebih atas sampah.

Misi :1. Mencipatakan ruang pendidikan berbasis masyarakat

2. Memberikan bentuk pembelajaran aktif yang berorientasi pada kehendak anak

3. Membangun "sekolah" yang sistematis dan penuh kasih sayang sebagai dasar pembentukan karakter yang kuat secara mental dan spiritual.

4. Menempatkan kembali moral dan etika sebagai unsur pendidikan yang sehat.

5. Menyelenggarakan pendidikan anak yang berkualitas serta komprehensif terhadap permasalahan biaya pendidikan.

Adapun fungsi dibentuknya Among Siwi adalah memberikan layanan pendidikan Anak Usia Dini, sebagai wadah untuk melestarikan permainan tradisional, dan sebagai ajang diskusi dan berbagi pengalaman. Selain itu, asas yang dibentuk Among Siwi adalah Asas Demokrasi, Asas Manfaat, Asas Kebersamaan, Asas Kemandirian, Asas Kebermaknaan, Asas Tolong-menolong.

PAUD Among Siwi memiliki kurikulum yang mengembangkan beberapa hal seperti, dalam pendidikan karakter pengajar memasukkan hal-hal yang harus diberikan pada peserta didik yaitu nilai keagamaan, budi pekerti (tata cara, sopan santun), olahraga dan seni budaya. Melalui pendidikan dasar tekologi, PAUD Among Siwi memberikan pengetahuan kepada anak tentang berbagai alat komunikasi seperti computer, televisi, handphone, telepon. Selain itu, dalam pendidikan dasar teknologi anak-anak juga belajar 
JIPSINDO No. 1, Volume 2, Maret 2015

tentang seni.Seni kriya juga memiliki keunggulan tersendiri, untuk membuat mainan tradisional seperti payungan, manukan, kitiran dll. Selain seni, pengetahuan sains juga menjadi pokok pembelajaran untuk membantu anak-anak memahami tentang keberanekaragaman alam. Untuk metode pembelajaran yang dilakukan di Among Siwi melalui belajar kelompok dan observasi langsung ke masyarakat. Selain itu, pendidikan lingkungan hidup juga menjadi pokok kurikulum pembelajaran, disini, anak-anak diajarkan tentang kebersihan diri, kebersihan lingkungan rumah maupun sekolah. Anak-anak juga belajar bagaimana memilih makanan yang sehat, cara merawat tanaman, belajar mengelola sampah untuk dijadikan pupuk kompos, mambuat mainan dari kardus dan kertas koran.

Menurut hasil wawancara dengan salah satu pendidik yang bernama Umi Khasanah bahwa di PAUD Among Siwi mengajarkan beberapa tari tradisional, dan permainan tradisioanal seperti ancakancak alis, cublak-cublak suweng, jamuran, dan sebagainya. Hal itulah yang diungkapkan Ketua Yayasan Among Siwi ini, yang telah mengajar selama dua tahun, dalam membangkitkan rasa kesadaran akan kebudayaan tradisonal terhadap anak." Karena dengan mengajarkan Budaya Tradisonal pada umur anak-anak seperti ini, sifat anak sangat mudah dibentuk karena mereka merupakan calon generasi bangsa" tegasnya lagi.Hal itulah yang dilakukan untuk mempertahankan budaya tradisonal di zaman Globalisasi ini. Bukan hanya belajar Budaya Tradisional, Among siwi mengajarkan pada anak,-anak tentang etika moral terhadap sesama, hal ini dilakukan oleh Bu Anis yang telah lama juga mengajar di PAUD Among Siwi. Niat tulusnya terpancar dari raut wajahnnya yang 
sangat sabar dengan dengan anak-anak di Among Siwi. Hal inilah yang membuat beliau dipilih sebagai Guru bimbingan Konseling. dalam proses pembelajaran sehari-hari Among Siwi selalu menggunakan bahasa daerah yaitu bahasa Jawa, sehingga selain memperkenalkan bahasa Jawa untuk anak juga bermaksud mengembangkan bahasa Jawa di tanah Jawa sendiri. jadi anakanak paham bagaimana berbahasa yang baik, halus dan sopan sesuai dengan tuntutan bahasa Jawa.

Penanaman karakter di PAUD Among Siwi juga mengintegrasikan melalui dolanan tradisional. Permainan atau dolanan tradisional yang dikenalkan pada anak-anak dalam pembelajaran seperti :

1. Dolanan "Dempo Ewa Ewo

Syair :Dempo ewa ewo hem, Ji walang kaji nden dem

Cangkromo jo Lombok Lombok abang dewo, Semedi ketiban dadi.

Cara main : Semua anak bergandeng tangan membentuk lingkaran, lalu salah satu orang membawa benda kecil misalnya balok kecil lalu balok kecil tersebut diputar, sambil bernyanyi syairnya. Jika pada syair "semedi ketiban dadi" maka kedapatan balok itu yang berjaga.Tuganya mengejar teman-temannya sampai dapat.

Manfaat : Permainan tradisi ini bersifat rekreatif ditujukan untuk menggembirakan di samping juga untuk mengembangkan kecerdasan kinestetik, naturalis, bahasa, music serta kecerdasan intrapersonal dan interpersonal.

Nilai karakter yang muncul : kebersamaan, konsistensi, tanggung jawab. 
JIPSINDO No. 1, Volume 2, Maret 2015

2. Ancak-ancak Alis

Syair :cak ancak alis, Si alis kabotan kidhang, Anak-anak kebo dhungkul,

Sidungkul bang bang teyot tigo rendheng, Enceng-enceng go go beluk,

Uni ne pathing selabut, Ulo opo ulo dumung,

Gedhene sak lumbung bandhung, Sawah iro sawah iro lagi ngopo wong Dheso?

Cara main; orang yang tertangkap harus menjawab pertanyaan di atas lalu dijawab dengan urut-urutan tata cara menanam padi, ngluku, ngaru, namping nyebar, ngurit, thandur, matur, ngrabuk, mekatuk, nguning ngabang, wiwitan dan terakhir panen. Setelah semua orang menyebutkan tahapan di atas lalu nyanyian dilanjutkan Nyang Pasar Kadipaten leh-oleh jadah manten.

"Nyang pasar beringharjo leh olehe opo?"

Kemudian orang yang tertangkap diajak menjauh dari kawan-kawan lalu ditanya mau pilih apa. Setelah semua tertangkap, lalu permainan dilanjutkan lagi. Orang yang terakhir tertangkap adalah yang jadi, teman yang lain membuat lingkaran dengan bergandengan tangan, kemudian salah satu orang bertanya, kidhang lanang po, kidhang wedok lalu orang yang ada di dalam harus berusaha keluar.

Manfaat : makna dari permainan ini adalah bersifat reflektif dan menggembirakan, selain itu juga bersifat memberikan pengetahuan tentang tahapan cara menanam padi.

Nilai karakter yang muncul: kerjasama, tanggung jawab, keberanian, kratifitas.

3. Sluku-sluku batok 
Syair :Sluku-sluku bathok, bathoke ela elo, siromo menyang solo, Leh olehe paying mutho, mak jenthit lo lo lobah, wong mati ora obah, yen obah medeni bocah, yen urip goleki dhuwit.

Cara main : semua anak membuat lingkaran lalu duduk, kaki diluruskan dan sambil bernyanyi.

Makna: Permainan ini bersifat menggembirakan dan memberikan pesan religious.

Itulah beberapa contoh permainan tradisional yang dikembangkan di Among Siwi, tidak hanya 3 permainan saja tetapi banyak permainan yang diperkenalkan ke anak-anak sehingga mereka bisa mendapatkan manfaat dari permainan tersebut, seperti melatih kerjasama, tanggung jawab, keberanian, kebersamaan, ketelitian, kedisiplinan, kreatifitas. Selain permainan tradisional untuk menanamkan nilai-nilai karakter, Among Siwi juga memberikan program "Tokoh Tamu" yang didatangkan dari berbagai profesi pekerjaan seperti profesi dokter, polisi, guru, reporter, polisi wanita, pemusik, penari, fotografer, dosen, pelukis dll. Didatangkan para tokoh dalam pembelajaran di Among Siwi, agar anak-anak lebih mengerti dan memahami keberagaman dan perbedaan bahwa dalam kehidupan bermasyarakat tidak hanya ada satu profesi saja tetapi banyak profesi pekerjaan dan anak-anak dapat termotivasi. Dengan demikian, program kurikulum yang diterapkan di PAUD Among Siwi berbasis karakter dan budaya sehingga mampu mengembangkan kecerdasan majemuk baik pengetahuan, sikap maupun ketrampilan.

\section{Simpulan}

Pendidikan Anak Usia Dini Among Siwi memiliki kurikulum yang mengembangkan beberapa hal seperti, nilai keagamaan, budi pekerti 
JIPSINDO No. 1, Volume 2, Maret 2015

(tata cara, sopan santun), olahraga dan seni budaya. Proses pembelajaran di Among Siwi ditekankan pada pengembangan karakter dan budaya. Melalui permainan tradisional, seni dan musik tradisional diharapkan mampu untuk mengembangkan kecerdasan anak baik pengetahuan, spiritual, sikap maupun ketrampilan. Penanaman karakter melalui permainan tradisional dapat dilihat melalui beberapa permainan seperti sluku-sluku bathok, ancakancak alis, dempo ewa-ewo, baris rampak dsb. Dimana dalam permainan, tarian dan nyanyian terdapat beberapa hal seperti Wiroso (perasaan), Wiromo (irama), Wirogo (psikomotorik /ketrampilan). Nilai-nilai karakter yang tertanam dalam diri anak seperti kerjasama, kebersamaan, kreatifitas, tanggung jawab, demokrasi, percaya diri, komitmen, dll, sehingga melalui permainan tradisional inilah jiwa dan karakter anak-anak usia dini dapat berkembang dengan baik.

\section{Saran}

1. Pemerintah sebaiknya senantiasa mendukung kegiatan pembelajaran di PAUD baik secara materiil maupun non materiil.

2. Guru harus terus mengembangkan kegiatan yang dapat mengembangkan kreatifitas anak usia dini.

3. Peran masyarakat menjadi sangat penting dalam rangka mencapai tujuan pendidikan PAUD. 


\section{Daftar Pustaka}

Barth, James. L. (1990). Methods of instruction in social studies education. New York: University Press of America.

Bimo Walgito. (1991). Psikologi social (Rev. ed.). Yogyakarta: Andi Offset

Darmiyati Zuhdi. (2008). Humanisasi pendidikan: menemukan kembali pendidikan yang manusiawi. Jakarta: Bumi Aksara.

Frankel, Jack R. (1977). How to teach about values, an analytic approach. London: Prentice-Hall, Inc

Hart, Gordon M. (1978). Values clarification for counselors: how counselors, social workers, psychologists and other human service workers can use available technique. Springfield-Illinois: CT-Publisher.

Kaswardi.(1993). Pendidikan nilai memasuki tahun 2000. Jakarta: Gramedia Widiasarana.

Kirchenbaum, H (1995). 100 Ways to enchance values and morality in two schools and youth setting. Massachusetts: A Simon \& Schuster Company.

Lickona, T. (1992). Educating for character, how our schools can teach respect and responsibility. New York: Bantam Books.

Mohammad Ali. (2005). Psikologi remaja: perkembangan peserta didik. Jakarta: Bumi Aksara.

Sjarkawi. (2006). Pembentukan kepribadian anak: peran moral, intelektual, emosional dan sosial sebagai wujud integritas membangun jati diri. Jakarta. Bumi aksara.

Tadkiratun Musfiroh. (2008). Character building. Yogyakarta: Tiara Wacana.

Ramli Zakaria. (2008). Pedoman penilaian sikap. Jakarta: Pusat Penilaian Pendidikan Balitbang Depdiknas. 